\title{
Impacts of Invasive Fishes on Fishery Dynamics of the Yamuna River, India
}

\author{
Atul K. Singh*, Abubakar Ansari, Sharad C. Srivastava, Pankaj Verma, A. K. Pathak \\ Exotic Fish Germplasm Section of Fish Health Management Division, National Bureau of Fish Genetic \\ Resources, Lucknow, India \\ Email: ${ }^{*}$ aksingh56@rediffmail.com
}

Received 16 May 2014; revised 30 June 2014; accepted 30 July 2014

Copyright $@ 2014$ by authors and Scientific Research Publishing Inc.

This work is licensed under the Creative Commons Attribution International License (CC BY).

http://creativecommons.org/licenses/by/4.0/

(c) (i) 0pen Access

\begin{abstract}
Invasion, spread and predominance of alien invasive fishes were studied in $950-\mathrm{km}$-long stretch of the Yamuna River. The fish yield ranged between $32 \mathrm{t} / \mathrm{km} / \mathrm{yr}$ to $240 \mathrm{t} / \mathrm{km} / \mathrm{yr}$ and the catch of alien invasive fishes dominated over local fishes in the fishery, which was over $96 \%$ at Etawah. The calculated Invasion Coefficient Index $\left(I_{x i}\right)$ of alien invasive fishes was in the range of 0.12 to 0.31 indicating a major loss to the local fish diversity. The calculated Pearson's correlation coefficient was found to have positive correlation of 0.757 and 0.710 for common carp and tilapia respectively with locally captured Indian major carps (IMC). The results of this study highlighted how unintentional spread of alien invasive fishes due to rapid aquaculture diversification and intensification has invaded into the Yamuna River causing severe loss to the local fishery. The invasion of alien fishes has been mapped for the Yamuna River at different locations using GIS tools. The results of this study invite attention on the management and sustainability of the local fishery and ecosystem health of the river.
\end{abstract}

\section{Keywords}

Alien Invasive Fishes, Invasion, Fish Yield, Local Fish Diversity, Invasion Coefficient Index, Yamuna River

\section{Introduction}

Introductions of alien fish species are an important part of human activities concerning aquatic ecosystems [1]. In India, over 300 alien fish species including 291 ornamental species, 31 aquaculture species and 3 larvicidal fishes are recorded [2]. These introductions are human-mediated and, may be intentional or unintentional. Both

${ }^{*}$ Corresponding author.

How to cite this paper: Singh, A.K., Ansari, A., Srivastava, S.C., Verma, P. and Pathak, A.K. (2014) Impacts of Invasive Fishes on Fishery Dynamics of the Yamuna River, India. Agricultural Sciences, 5, 813-821.

http://dx.doi.org/10.4236/as.2014.510086 
types of introductions can cause bioinvasions i.e. introductions assisted by humans and natural range expansions. Alien invasive fishes are considered as one of the major causes of erosion or devastation of the native fish biodiversity in freshwater ecosystems [1]-[4]. Most of the intentional introductions aimed to bring benefits to fishery management, aquaculture and fishpond production or in the case of natural ecosystems, by a need to fill vacant niches, to increase production and to provide new objects for sport fishing and ornamental fish [2] [3]. In the past, there was scanty effort made to the risk assessment of the introductions either intentional or unauthorized. However, the latter was not thoroughly premeditated, often because the negative impacts of the alien fish species became apparent only some time after the alien species were introduced and established in the ecosystem. During the last decade, river ecosystems in India have been suffering from heavy human intervention, resulting in habitat loss and declined fishery of local fish species [5] [6]. Many freshwater fish species have become critically declined [7]. The main reasons attributable to the decline in fishes are habitat destruction and fragmentation [8], water abstraction, industries and private use [9]-[12] in general and increased incidences of alien invasive species in particular [2] [13]. Today the fish diversity and associated habitats management are emerging as a great challenge particularly in view of invasion of alien fish species [1] [2] [14] since alien invasive fishes have been identified as one of the chief threats to the aquatic ecosystem and the biodiversity [2] [15]. Escaped invasive alien species from inadvertent releases can interact negatively with native ones by altering availability or quality of nutrients, competing for food and physical resources, changing habit structure and affecting gene flow species diversity [15] [16]. It is now widely recognized that invasion of alien species is one of the most important factors endangering fish biodiversity and breaking down geographical barriers [15] [16].

In view of the above documented facts, the objective of this study was to generate data to document the spread of alien invasive fishes in the Yamuna River, their distribution and the extent to which it has interacted with the local fish diversity. Present investigation also attempted to quantify the invasion and trade off the local fish diversity and ecosystem services viz-a-viz socio-economic changes. The paper presents a simple and generalizable non-species specific method for characterizing and assessing ecosystem invasions on measurable scale using spatially abundance data on the local and alien fish species. The approach is flexible and can be applied in different biomes, at multiple scales and to different groups of taxa quantifying general processes of fish invasion which thereby increases our understanding on invasion biology and the efficiency of pest surveillance and control.

\section{Materials and Methods}

The Yamuna River is largest tributary of the Ganga River System the biggest river system in the country. The river Yamuna traverses a distance of approximately $950 \mathrm{~km}$ in the plain starting from Saharanpur district of the State of Uttar Pradesh to the confluence with river Ganga at Allahabad. We have collected information on the occurrences, abundance, and fish yield from the Yamuna River passing through various districts of the state of Uttar Pradesh (Figure 1). The entire stretch of the Yamuna River is used for various human activities including fisheries through which the State Department earns substantial revenue by leasing out the stretches of the River to different fishermen societies for fishing purpose. In this study, we have generated data from 15 landing sites covering major cities along the river. Data from different landing sites was generated every quarter during the year May 2011 to March 2013.

Fishermen used dragnets of different mesh sizes ranging from $1-6 \mathrm{~cm}$ for fishing purpose. The fish yield of different river stretches was assessed with the help of the fishermen through field surveys undertaken on regular basis during the aforesaid period. The fish yield of per km river stretch at each landing centers was estimated based on our monthly catch data with the help of fishermen commercially catching the fish from the river at different landing sites. The \% age contribution of local and alien invasive fishes in the total yield was calculated. From the total captured fishes at a landing sites, the over-all fish diversity was examined for each sampling locations with the help of taxonomic descriptions described by Talwar \& Jhingran (1991) [17] and FAO identification sheet [18]. The captured local fish species were sub grouped as Indian major carps (Catla catla, Labeo rohita and Cirrhinus mrigala), catfishes (Wallago attu, Sperata spp., Clupesoma garua, Rita rita and other important ones) and miscellaneous fishes which were minor carps, weed fishes and other small fishes. The contribution of these subgroups for total catch was also determined for each sampling locations. The major groups of local fish as well as different alien invasive fish species were subjected to the measurements for length (cm) and weight (g) of randomly selected 25 specimens of each species at different sampling sites.

Based on the location specific fish diversity and the total number of alien invasive fish species observed, the 


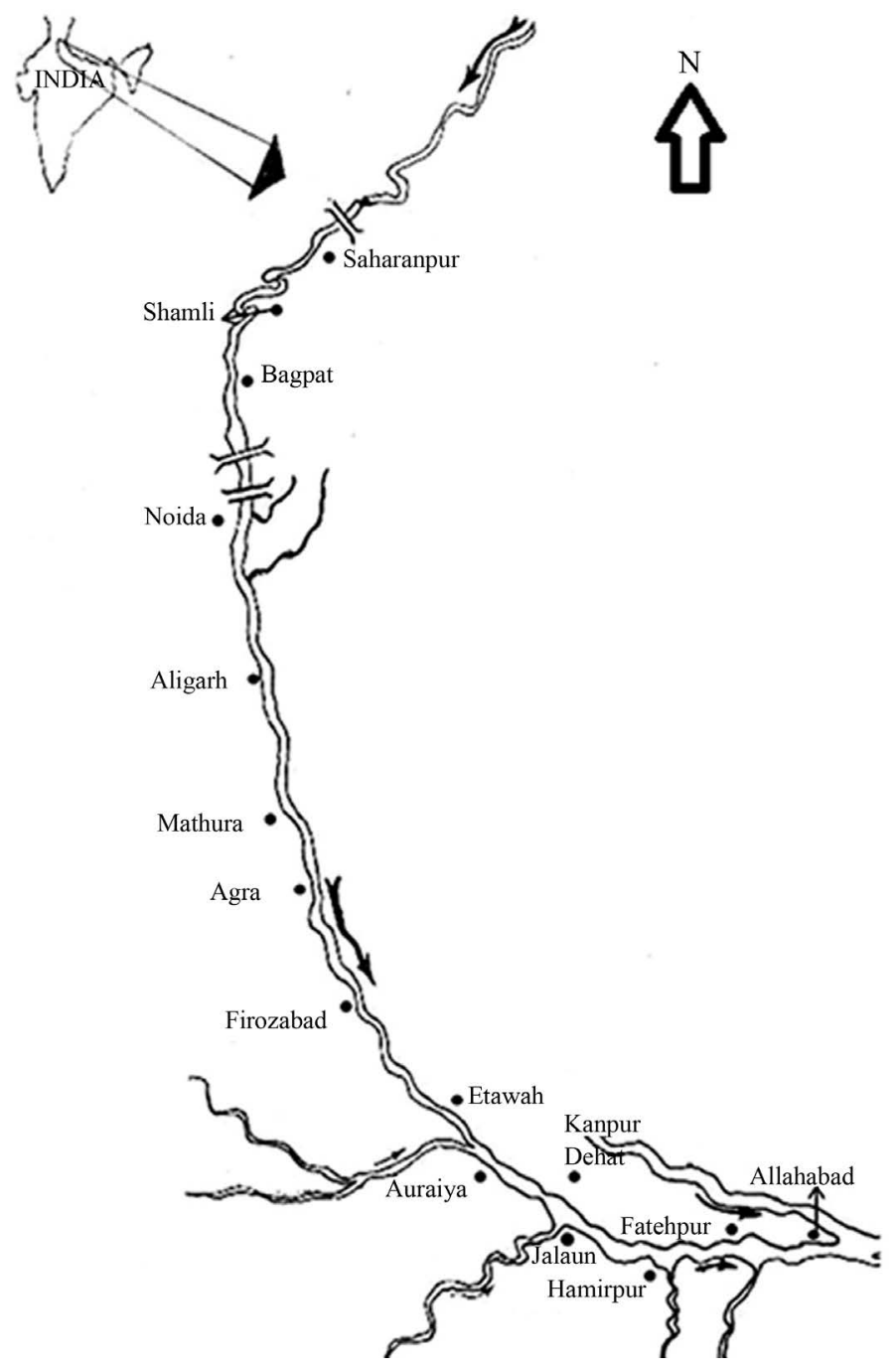

Figure 1. Sampling locations in the Yamuna River.

Invasion Coefficient Index $\left(I_{x i}\right)$ was calculated using the formula:

$$
I_{x i}=E \eta / N
$$

where $I_{x i}$ was Invasion Coefficient Index; En was number of alien invasive fishes species captured at each study site and $N$ was number of all the fish species caught at the sampling site. Invasion Coefficient Index represented the level to which local fish species were invaded by exotic species. The Invasion Coefficient Index ranged on a scale of 0 to 1 representing the invasion conditions. The 0 level of invasion showed minimum level of loss to the fish diversity where 1 represents the highest degree of invasion consequently total loss to the biodiversity.

For GIS mapping, we used the administrative-boundary vector map of India at district level (group of blocks) procured from the Survey of India at a scale of 1:1 000,000. The Survey of India toposheet for Uttar Pradesh at a scale of 1:250,000 was also used for mapping the exotic and local fish species in different stretches of the Yamuna River. The catch-composition data on local and alien invasive fish species were compiled from different stretches of the river at the district level. These compiled data were used to prepare the spatial database and thematic maps with the help of PCI Geometric 9.1 Prime, Arc GIS 8.3 with Arc Info software

(www.pcigeomatics.com; www.esri.com). From the administrative boundary map of India, the administrative boundary of Uttar Pradesh was extracted at district level using the extract utility from the Arc Tool box of Arc GIS 8.3. The toposheet of Uttar Pradesh at a scale 1:250 000 was geo-referenced and the Yamuna River from this toposheet was digitized and analyzed. The administrative-boundary vector map of Uttar Pradesh was raste- 
rized in Geometric 9.1 Prime and was geo-referenced with the toposheet of Uttar Pradesh. The geo-referenced layer of Uttar Pradesh district administrative boundary was again converted using the raster-to-vector conversion utility of Geometric 9.1. The digitized layer of the Yamuna River was superimposed and added with the district polygon vector layer. The Yamuna River vector layer was divided into different stretches using the district boundary as a clip segment through which the river passes. Attribute tables with respect to these two vector layers were prepared, and the collected data on exotic and local fish catch-composition were entered into the attribute tables of these layers. Vector layers of the Yamuna River and of the district-boundary polygons were exported to the Arc coverage file format for analysis, querying and thematic-map generation. The coverage line layer for the Yamuna River and polygon layer for districts of Uttar Pradesh were used in Arc GIS 8.3 with Arc Info for analysis and map generation. Different GIS tools were applied spatially on attribute tables, and thematic maps were generated.

\section{Statistical Analysis}

All data were presented as mean. The length-weight regression $\left(r^{2}\right)$ was calculated by the method of least squares by grouping the sample data into several short length groups and fitting the regression of logarithmic value of the average weight of fishes. The grouping was done according to the size ranges of the collected fish. The degree of adherence was then determined on the basis of length-weight regressions and it was calculated using the following formula:

$$
r^{2}=\frac{\sum x y-n x^{-} y^{-}}{\sqrt{\left(\sum x^{2}-n x^{-2}\right)\left(\sum y^{2}-n y^{-2}\right)}}
$$

where $n$ was total number of length group; $x^{-}$was mean of length $(x)$ and $y^{-}$was mean of weight $(y)$.

Further Pearson's correlation coefficient was calculated between the different alien invasive fish species recorded at a locations with the local fish species groups i.e. IMC, catfish and miscellaneous fishes. Data obtained for different groups were subjected to statistical analysis using the Statistical Package SPSS (Version 16).

\section{Results}

The data collected from the river showed that 63 fish species were present in the river which belonged to 8 orders, 18 families, 39 genus and 63 species. Out of total 63 recorded species, 53 were identified as local and 10 alien invasive fish species (Figure 2). The recorded data showed that order Cypriniformes was dominated by Cyprinidae family representing 15 genera and 25 species and constituted $40 \%$ of the total catch.

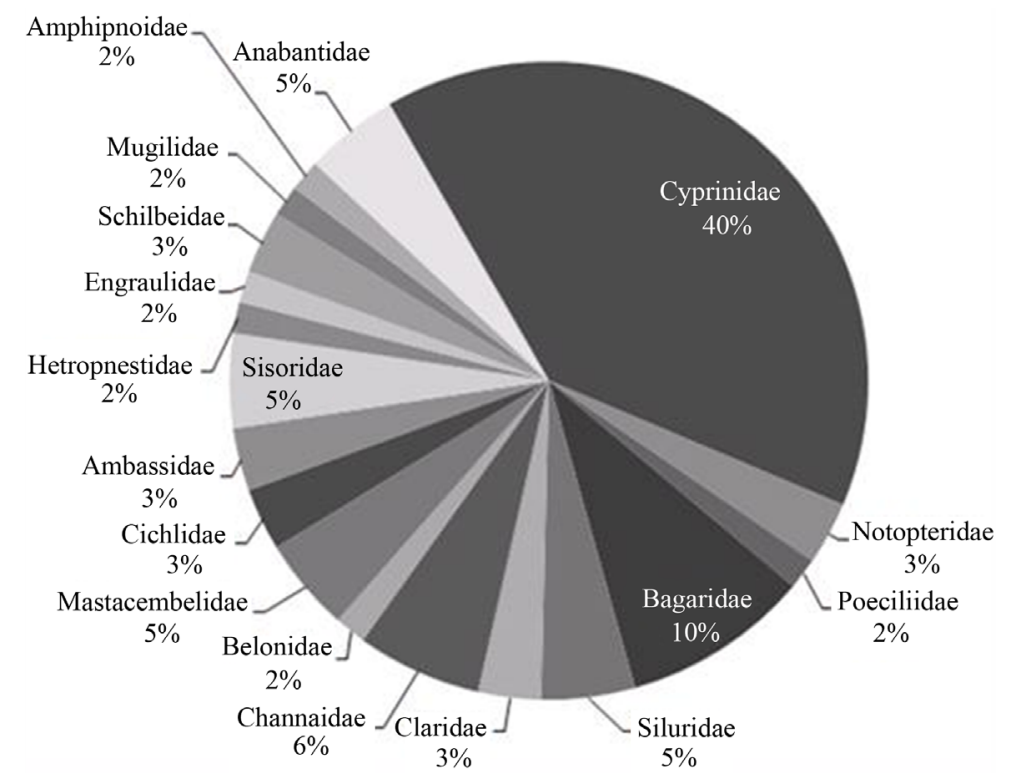

Figure 2. Family wise fish composition details of the Yamuna River. 
The fishery of the river showed a blend of local and exotic species throughout the year. However, there was a predominance catch of alien invasive fishes at most of the sampling locations. The alien invasive fish species present in the catches were identified Cyprinus carpio Var. communis, C. carpio Var specularis, Carassius auratus, Oreochromis niloticus, O. mossambicus, Clarias gariepinus, Aristichthys nobilis, Hypophthalmichthys molitrix, Ctenopahyngodon idella, Gambusia affinis. The yield (t/km/yr) of different local and alien invasive fishes species at different sampling locations was maximum $(220 \mathrm{t} / \mathrm{km} / \mathrm{yr})$ at Allahabad and minimum $(40 \mathrm{t} / \mathrm{km} / \mathrm{yr})$ at Saharanpur (Figure 3). The yield contribution of different fish groups were recorded and the catch for Indian major carps ranged from 4.8 to $11.5 \mathrm{t} / \mathrm{km} / \mathrm{yr}$ while local catfishes constituted 9.8 to $52.6 \mathrm{t} / \mathrm{km} / \mathrm{yr}$ and miscellaneous fishes constituted 42.6 to $106 \mathrm{t} / \mathrm{km} / \mathrm{yr}$ (Figure 3).

Common carp and tilapia constituted the major bulk of captured alien invasive fishes at most of the locations. Common carp was captured in the range of $19.7 \%$ to $58.6 \%$ in the size group of fry, fingerlings to large one up to $22.5 \mathrm{~kg}$ while tilapia in the size range of $1.5 \mathrm{~g}$ to $2.8 \mathrm{~kg}$ constituting $13.2 \%$ to $66.9 \%$ of total alien invasive fishes caught. The highest contribution of common carp was at Saharanpur (58.6\%) and lowest at Etawah (19.7\%). The length-weight correlation $\left(r^{2}\right)$ value of common carp was above 0.67 and maximum value was 0.934. The tilapia was captured maximally at Etawah where we recorded $66.9 \%$ capture and the minimum catch of tilapia was $13.2 \%$ at Shamli. African catfish was also captured in the range of $4.2 \%$ to $13.5 \%$ of the total alien invasive fishes captured at different stations and the $r^{2}$ value was in the range of 0.795 to 0.977 . Maximum catch of C. gariepinus (13.5\%) was at Aligarh while largest size $(18.5 \mathrm{~kg})$ of the fish was recorded at Noida from Hindon River (a tributary of the Yamuna River). It was observed that Gambusia affinis was present at Sharanpur, Shamli, Hamirpur and Allahabad only. The calculated Invasion Coefficient Index revealed that it was highest 0.31 at Etawah and minimum 0.12 at Shamli (Figure 3). The Invasion Coefficient Index was correlated with the fish diversity where we found that places having higher Invasion Coefficient Index had lower local fish diversity (Figure 3). Exotic carps comprising of grass carp, silver carp and bighead were also found in large size (1.5 to $12.8 \mathrm{~kg}$ ) and they constituted $2.8 \%$ to $19.7 \%$ and their length-weight regression was in the range of 0.715 to 0.985. The contribution of alien invasive fishes ranged from $40.0 \%$ to $96.0 \%$ at different locations in a year. The presence of different percentage classes of alien invasive fishes along the Yamuna River was mapped using GIS and the details are presented (Figure 4).

The calculated Pearson's correlation coefficient for yield of alien invasive fish species with local fish groups showed that there was a positive correlation of common carp (0.757) and tilapia (0.712) with Indian major carps (Table 1). The exotic carps were also positively correlated (0.631) with Indian major carps. However, in case of

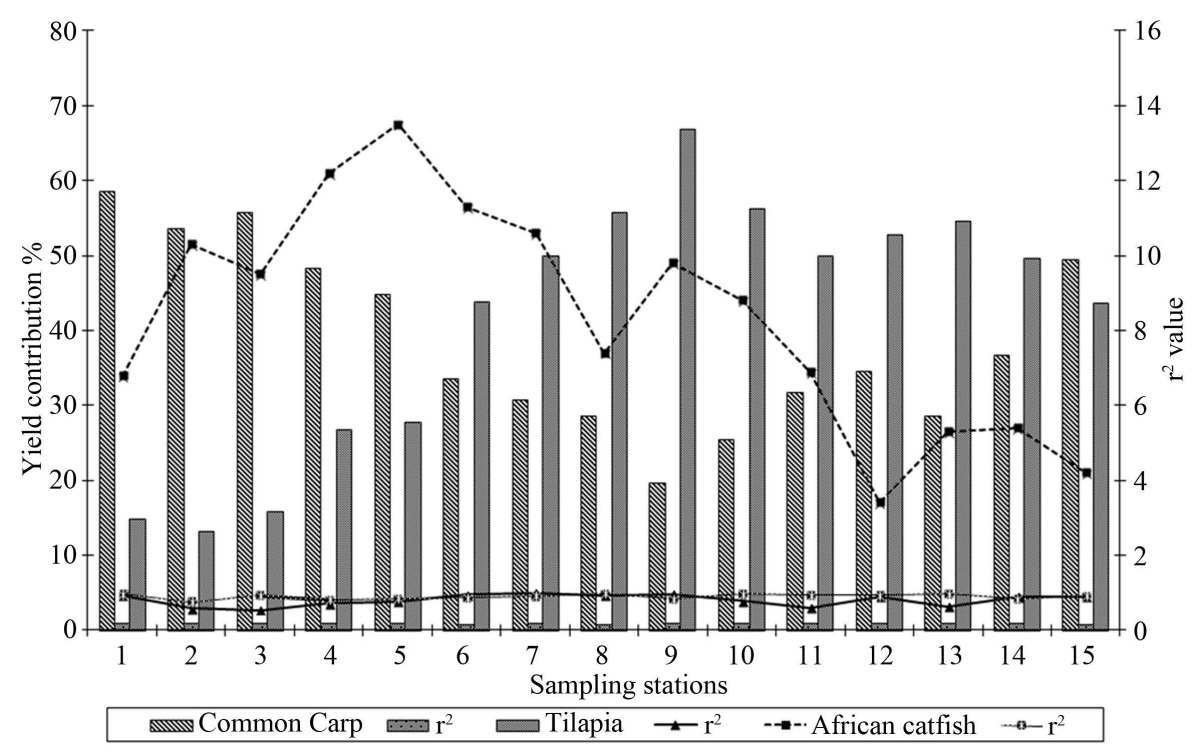

Figure 3. Fish yield (t/km/yr) of local and alien invasive fishes at different locations and Invasion Coefficient Index (1-Saharanpur; 2-Shamli; 3-Bagpat; 4-Noida; 5-Aligarh; 6Mathura; 7-Agra; 8-Firozabad; 9-Etawah; 10-Auraiya; 11-Kanpur Dehat; 12-Jalaun; 13-Hamirpur; 14-Fatehpur; 15-Allahabad). 


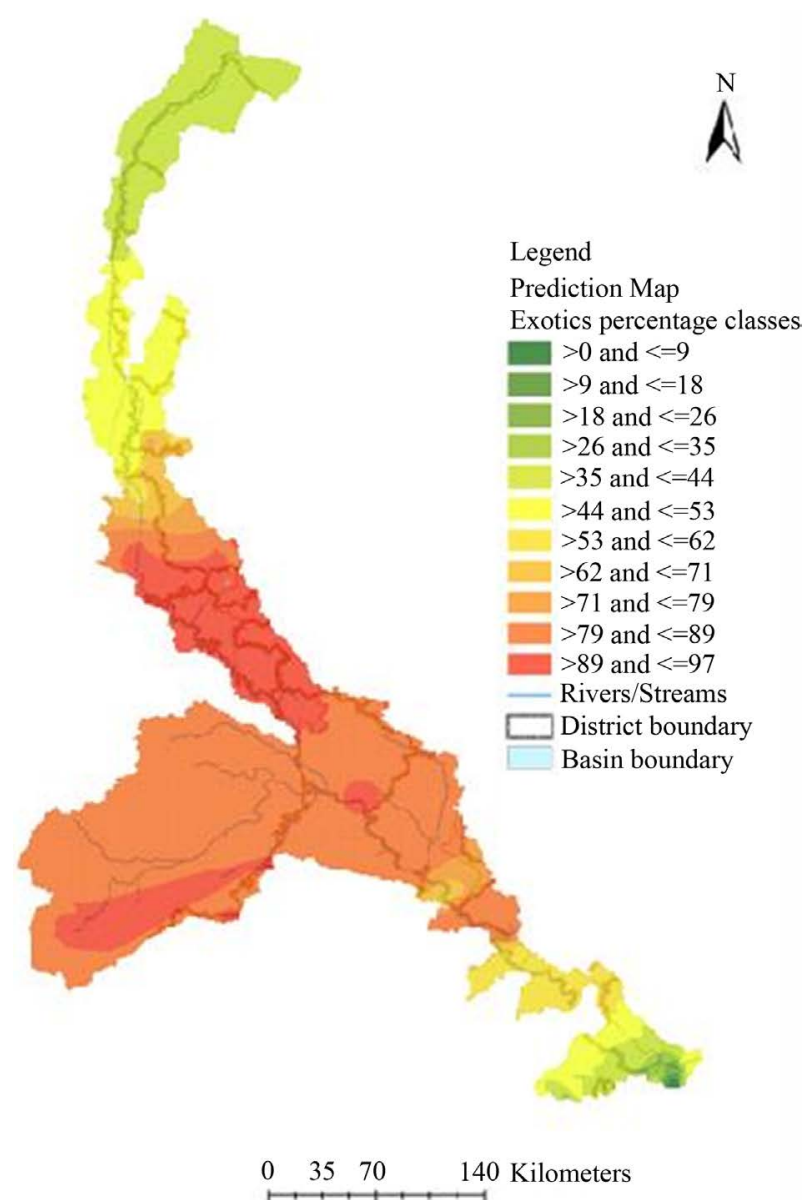

Figure 4. GIS mapping for different percentage classes of alien invasive fishes in the Yamuna River.

Table 1. Pearson's correlation coefficient of different invaded fish species with local fish groups in the Yamuna River.

\begin{tabular}{cccc}
\hline \multirow{2}{*}{ Alien invasive fishes } & \multicolumn{3}{c}{ Correlation coefficient value with local fish groups } \\
\cline { 2 - 4 } & Indian major carps & Catfishes & Miscellaneous \\
\hline Common carp & 0.7571 & 0.1270 & 0.5430 \\
Tilapia & 0.7101 & 0.1125 & 0.5039 \\
African catfish & 0.1544 & 0.0912 & 0.1631 \\
Exotic carps & 0.6312 & 0.1213 & 0.4651 \\
\hline
\end{tabular}

local catfishes the correlation coefficient was poor for all alien invasive fishes. The Pearson's coefficient correlation for the miscellaneous local fish species showed positive correlation particularly with common carp and tilapia (Table 1).

\section{Discussion}

There is hardly any published information on the fish diversity of the Yamuna River. However, results of this study showed that the Yamuna River harbours 63 local fish species even though the River has degraded considerably over the years [5] [6]. A total of 93 fish species classified under 73 genera, 27 families and 9 orders was reported earlier from the river where maximum diversity was encountered in the downstream stretch and least in 
the midstream, influenced by the water quality [5] [6]. Interestingly the fishery of the river is now largely contributed by the feral alien invasive fishes, the yield of which varied from place to place. Some of the river stretch for example Etawah, was so well planted with alien invasive fishes that its yield was mainly for Oreochromis niloticus contributing up to $96 \%$ of total catches. The yield of tilapia was high between Gautam Buddhanagar to Etawah stretch of the river while common carp dominated below Etawah up to Allahabad possibly due to improvement of water qualities [5] [6]. The fishery of the Yamuna River indicated that there has been decline in the fish yield over the years [5] [6]. However, we recorded increased trend of alien invasive fishes in fishing which was mainly because of increased production of the alien invasive fishes. However, increased production of alien invasive fishes resulted in loss of biodiversity which was changing fast due to different degree of invasion and consequential habit loss on account of the invaded alien invasive fishes species [1] [2] [19]. Freshwater fish diversity of the river is enormous [20]-[22] however; the observed impacts of invasive alien fish species emphasized that the biodiversity of the river was adversely affected [2]-[4].

The risks associated with the invasion of alien fish species were growing with increasingly rapid diversification of aquaculture activities with alien invasive fish species and unregulated transportations [2] [16]. Alien invasive fish species claimed the losses of fishery of local species and genetic diversity as per the results of this study. Such changes were apparently understood to destroy the structure and function of riverine ecosystem [1] [15]. The fish diversity was measured by Invasion Coefficient Index pointing out the number of fish species the river was sustaining. However, due to increased spread of invasive alien fishes, there were declines in habitat quality and more invasions by alien fishes [2] [15] [23]. Many local species particularly Indian major carps were found to considerably decline and were likely extirpated from some of the stretches in the Yamuna River. At the upper most part of the river (Saharanpur) various fish species were present while downstream from Gautam Buddhanagar to Hamirpur most of the local fish species appeared either vanished or extirpated which however, showed increased diversity at Allahabad. It was obvious that the increased incidence of invasion of alien invasive fishes caused severe resource competition and fisher folk had to remain deprived of catches for local species which were more valued and preferred rather depending on the catches of alien invasive fishes mostly. Loss of local fish resource availability was understood as a key factor that influenced invasion success and processes [24] [25]. The process of species invasion appeared to happen in three successive stages which were initial dispersal due to increased human activities; establishment of self-sustaining population and spread along the river stretches. The last two stages were found contingent upon the first one and were critical [15] [26]. Despite the increasing literature on invasive fish species, this study is the first to quantify the impact of invasion of alien invasive fishes in the Yamuna River. Tilapia, African catfish, silver carp, gambusia are unequivocally reported to prove the devastating impacts on aquatic ecosystem [2]. Alien species can cause severe changes in ecosystem's functioning and are currently recognized as principal agents of ecological changes [27]-[29]. Understanding the factors that influence the success of ecologically and economically damaging biological invasions is of prime importance. Results of this study documented that invasive populations typically exhibited potential of reducing fish genetic diversity, suggesting that invasions overweigh large confounding factors associated with loss of fish biodiversity [1] [2].

\section{Conclusion}

The deliberate or accidental introduction of species outside their native range was identified as a key component of the human induced biodiversity crisis, harming native species and disturbing ecosystems processes [23] [28]. The greater the incidence of introduction of alien invasive fishes in a region, the higher the probability that some of them become invasive and will hence cause ecological or economic damage [23] [30] [31]. It is therefore, suggested that prevention and early detection of alien invasive species are necessary to control the spread of invasive alien species. Further, risk assessment is very important and should be made mandatory to manage the intentional introductions. Our broad-scale analyses of the data presented in this study help local researchers to focus on alien invasive species to control them particularly in the biodiversity sensitive areas of freshwater.

\section{Acknowledgements}

Authors are grateful to Dr. J. K. Jena, Director NBFGR for his generous support and guidance. The financial support of Uttar Pradesh State Biodiversity Board, Lucknow is thankfully acknowledged. 


\section{References}

[1] García-Berthou, E. (2007) The Characteristics of Invasive Fishes: What Has Been Learned So Far? Journal of Fish Biology, 71, 33-55. http://dx.doi.org/10.1111/j.1095-8649.2007.01668.x

[2] Singh, A.K. and Lakra, W.S. (2011) Risk and Benefit Assessment of Alien Fish Species of the Aquaculture and Aquarium Trade into India. Reviews in Aquaculture, 3, 3-18. http://dx.doi.org/10.1111/j.1753-5131.2010.01039.x

[3] Lakra, W.S., Singh, A.K. and Ayyappan, S. (Eds.) (2008) Fish Introductions in India: Status, Potential and Challenges. Narendra Publishers, New Delhi.

[4] De Silva, S.S., Nguyen, T.T.T., Turchini, G.M., et al. (2009) Alien Species in Aquaculture and Biodiversity: A Paradox in Food Production. AMBIO: A Journal of the Human Environment, 38, 24-28. http://dx.doi.org/10.1579/0044-7447-38.1.24

[5] Sinha, M. (2006) Riverine Fisheries of India. In: Ayyappan, S., Jena, J.K., Gopalakrishnan, A. and Pandey, A.K., Eds., Handbook of Fisheries and Aquaculture, ICAR Publication, New Delhi, 142-157.

[6] Vass, K.K., Mondal, S.K., Samanta, S., et al. (2010) The Environment and Fishery Status of the River Ganges. Aquatic Ecosystem Health \& Management, 13, 385-394. http://dx.doi.org/10.1080/14634988.2010.530139

[7] Sarkar, U.K., Dubey, V.K., Singh, A.K., et al. (2012) Recent Occurrences of Exotic Freshwater Fishes in the Tributaries of River Ganga Basin: Abundance, Distribution, Risks, Conservation Issues. Environmentalists, 32, 476-484. http://dx.doi.org/10.1007/s10669-012-9412-7

[8] Cuizhang, F., Jihua, W., Jiakuan, C., et al. (2003) Freshwater Fish Biodiversity in the Yangtze River Basin of China: Patterns, Threats and Conservation. Biodiversity and Conservation, 12, 1649-1685. http://dx.doi.org/10.1023/A:1023697714517

[9] Szollosi-Nagy, A. (2004) In: Proceedings of the United Nations Seminar, Delft, 25-26 November 2004.

[10] Ricciardi, A. and Rasmussen, J.B. (1999) Extinction Rates of North American Freshwater Fauna. Conservation Biology, 13, 1220-1222. http://dx.doi.org/10.1046/j.1523-1739.1999.98380.x

[11] Gibbs, J.P. (2000) Wetland Loss and Biodiversity Conservation. Conservation Biology, 14, 314-317. http://dx.doi.org/10.1046/j.1523-1739.2000.98608.x

[12] Dawson, T.P., Berry, P.M. and Kampa, E. (2003) Climate Change Impacts on Freshwater Wetland Habitat. Journal of Nature Conservation, 11, 25-30. http://dx.doi.org/10.1078/1617-1381-00031

[13] Copp, G.H., Bianci, P.G., Bogutskaya, N.G., Erős, T., Falka, I., Ferreira, M.T., et al. (2005) To Be, or Not to Be, a Non-Native Freshwater Fish. Journal of Applied Ichthyology, 21, 242-262. http://dx.doi.org/10.1111/j.1439-0426.2005.00690.x

[14] Dudgeon, D., Arthington, A.H., Gessner, M.O., Kawabata, Z.I., Knowler, D.J., Lévêque, C., et al. (2006) Freshwater Biodiversity: Importance, Threats, Status and Conservation Challenges. Biological Reviews, 81, 163-182. http://dx.doi.org/10.1017/S1464793105006950

[15] Laprieur, F., Beauchard, O., Blanchet, S., Oberdorff, T. and Brosse, S. (2008) Fish Invasions in the World’s River Systems: When Natural Processes Are Blurred by Human Activities. PLoS Biology, 6, e28. http://dx.doi.org/10.1371/journal.pbio.0060028

[16] Xu, H., Qiang, S., Han, Z., Guo, J., Huang, Z., Sun, H., et al. (2006) The Status and Causes of Alien Species Invasion in China. Biodiversity \& Conservation, 15, 2893-2904. http://dx.doi.org/10.1007/s10531-005-2575-5

[17] Talwar, P.K. and Jhingran, A. (1991) Inland Fishes of India and Adjacent Countries. Oxford and IBH Publishing Co., New Delhi, 1 and 2, 115-116.

[18] Fischer, W. and Bianchi, G. (Eds.) (1984) FAO Species Identification Sheets for Fishery Purposes. Western Indian Ocean (Fishing Area 51). Prepared and Printed with the Support of the Danish International Development Agency (DANIDA). FAO, Rome, Vol. 1-6.

[19] De Silva, S.S., Nguyen, T.T.T., Abery, N.W. and Amarasinghe, U.S. (2006) An Evaluation of the Role and Impacts of Alien Finfish in Asian Inland Aquaculture. Aquaculture Research, 37, 1-17.

[20] Bilgrami, K.S. (1991) Biological Profile of the Ganga: Zooplankton, Fish, Birds and Other Minor Fauna. In: Krishnamurti, C.R., Bilgrami, K.S., Das, T.M. and Mathur, R.P., Eds., The Ganga: A Scientific Study, Northern Book Centre, New Delhi, 81-94.

[21] Kapoor, D., Dayal, R. and Ponniah, A.G. (2002) Fish Biodiversity of India. National Bureau of Fish Genetic Resources, Lucknow.

[22] Lakra, W.S., Singh, A.K. and Mahanta, P.C. (Eds.) (2009) Fish Genetic Resources. Narendra Publishers, New Delhi, $308 \mathrm{p}$.

[23] Clavero, M. and García-Berthou, E. (2005) Invasive Species Are a Leading Cause of Animal Extinctions. Trends in 
Ecology and Evolution, 20, 110-119. http://dx.doi.org/10.1016/j.tree.2005.01.003

[24] Davis, M.A., Grime, J.P. and Thompson, K. (2000) Fluctuating Resources in Plant Communities: A General Theory of Invasibility. Journal of Ecology, 88, 528-534. http://dx.doi.org/10.1046/j.1365-2745.2000.00473.x

[25] Prieur-Richard, A.H., Lavorel, S., Grigulis, K. and Santos, A.D. (2000) Plant Community Diversity and Invisibility by Exotics: Invasion of Mediterranean Old Fields by Conyza bonariensis and Conyza canadensis. Ecological Letters, 3, 412-422. http://dx.doi.org/10.1046/j.1461-0248.2000.00157.x

[26] Singh, A.K., Pathak, A.K. and Lakra, W.S. (2010) Invasion of an Alien Invasive Fishes-Common Carp, Cyprinus carpio L. (Actinopterygii: Cypriniformes: Cyprinidae) in the Ganga River, India and Its Impacts. Acta Ichthyologica Et Piscatoria, 40, 11-19. http://dx.doi.org/10.3750/AIP2010.40.1.02

[27] Pimentel, D., Zuniga, R. and Morrison, D. (2005) Update on the Environmental and Economic Costs Associated with Alien-Invasive Species in the United States. Ecological Economics, 52, 273-288. http://dx.doi.org/10.1016/j.ecolecon.2004.10.002

[28] Byrnes, J.E., Reynolds, P.L. and Stachowicz, J.J. (2007) Invasions and Extinctions Reshape Coastal Marine Food Webs. PLoS ONE, 2, e295. http://dx.doi.org/10.1371/journal.pone.0000295

[29] Zenetos, A., Gofas, S., Verlaque, M., Cinar, M.E., Raso, J.E.G., Bianchi, C.N., et al. (2010) Alien Species in the Mediterranean Sea by 2010. A Contribution to the Application of European Union's Marine Strategy Framework Directive (MSFD). Part I. Spatial Distribution. Mediterranean Marine Science, 11, 381-493. http://dx.doi.org/10.12681/mms.87

[30] Jeschke, J.M. and Strayer, D.L. (2005) Invasion Success of Vertebrates in Europe and North America. Proceedings of the National Academy of Sciences of the United States of America, 102, 7198-7202. http://dx.doi.org/10.1073/pnas.0501271102

[31] Pyšek, P. and Richardson, D.M. (2006) The Biogeography of Naturalization in Alien Plants. Journal of Biogeography, 33, 2040-2050. http://dx.doi.org/10.1111/j.1365-2699.2006.01578.x 
Scientific Research Publishing (SCIRP) is one of the largest Open Access journal publishers. It is currently publishing more than 200 open access, online, peer-reviewed journals covering a wide range of academic disciplines. SCIRP serves the worldwide academic communities and contributes to the progress and application of science with its publication.

Other selected journals from SCIRP are listed as below. Submit your manuscript to us via either submit@scirp.org or Online Submission Portal.
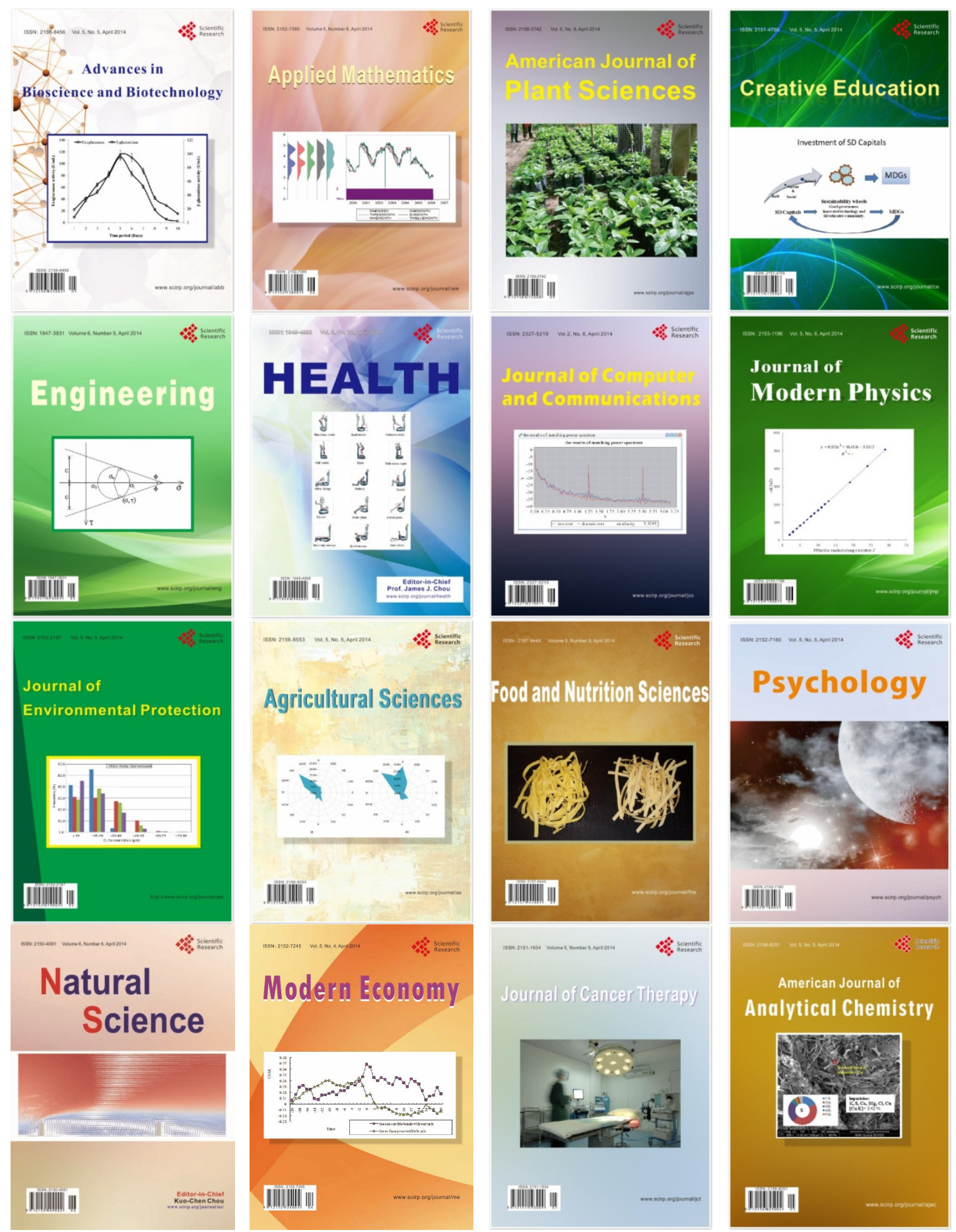